ISLAM AND THE PRAYER ECONOMY

The International African Library is a major monograph series from the International African Institute and complements its quarterly periodical Africa, the premier journal in the field of African studies. Theoretically informed ethnographies, studies of social relations 'on the ground' which are sensitive to local cultural forms, have long been central to the Institute's publications programme. The $I A L$ maintains this strength but extends it into new areas of contemporary concern, both practical and intellectual. It includes works focused on problems of development, especially on the linkages between the local and national levels of society; studies along the interface between the social and environmental sciences; and historical studies, especially those of a social, cultural or interdisciplinary character. 


\section{International African Library}

\section{General Editors}

\section{J. D. Y. Peel, Colin Murray and Suzette Heald}

Titles in the series:

1 Sandra T. Barnes Patrons and power: creating a political community in metropolitan Lagos

2 Jane I. Guyer (ed.) Feeding African cities: essays in social history

3 Paul Spencer The Maasai of Matapato: a study of rituals of rebellion

4 Johan Pottier Migrants no more: settlement and survival in Mambwe villages, Zambia

5 Gunther Schlee Identities on the move: clanship and pastoralism in northern Kenya

6 Suzette Heald Controlling anger: the sociology of Gisu violence

7 Karin Barber I could speak until tomorrow: oriki, women and the past in a Yoruba town

8 Richard Fardon Between God, the dead and the wild: Chamba interpretations of religion and ritual

9 Richard Werbner Tears of the dead: the social biography of an African family

10 Colin Murray Black Mountain: land, class and power in the eastern Orange Free State, 1880 s to 1980 s

11 J. S. Eades Strangers and traders: Yoruba migrants, markets and the state in northern Ghana

12 Isaac Ncube Mazonde Ranching and enterprise in eastern Botswana: a case study of black and white farmers

13 Melissa Leach Rainforest relations: gender and resource use among the Mende of Gola, Sierra Leone

14 Tom Forrest The advance of African capital: the growth of Nigerian private enterprise

15 C. Bawa Yamba Permanent pilgrims: the role of pilgrimage in the lives of West African Muslims in Sudan

16 Graham Furniss Poetry, prose and popular culture in Hausa

17 Philip Burnham The politics of cultural difference in northern Cameroon

18 Jane I. Guyer An African niche economy: farming to feed Ibadan, 1968-88

19 A. Fiona D. Mackenzie Land, ecology and resistance in Kenya, 1880-1952

20 David Maxwell Christians and chiefs in Zimbabwe: a social history of the Hwesa people c. 1870s-1990s

21 Birgit Meyer Translating the devil: religion and modernity among the Ewe in Ghana

22 Deborah James Songs of the women migrants: performance and identity in South Africa

23 Christopher O. Davis Death in abeyance: illness and therapy among the Tabwa of Central Africa

24 Janet Bujra Serving Class: masculinity and the feminisation of domestic service in Tanzania

25 T. C. McCaskie Asante identities: history and modernity in an African village $1850-1950$

26 Harri Englund From war to peace on the Mozambique-Malawi borderland

27 Anthony Simpson 'Half-London' in Zambia: contested identities in a Catholic mission school

28 Elisha Renne, Population and progress in a Yoruba town

29 Belinda Bozzoli, Theatres of struggle and the end of apartheid

30 R. M. Dilley Islamic and caste knowledge practices among Haalpulaar'en in Senegal: between mosque and termite mound

31 Colin Murray and Peter Sanders Medicine murder in colonial Lesotho: the anatomy of a moral crisis

32 Benjamin F. Soares Islam and the prayer economy: history and authority in a Malian town 


\section{ISLAM AND THE PRAYER ECONOMY}

\section{HISTORY AND AUTHORITY \\ IN A MALIAN TOWN}

BENJAMIN F. SOARES

EDINBURGH UNIVERSITY PRESS

for the International African Institute, London 
(C) Benjamin F. Soares, 2005

Edinburgh University Press Ltd

22 George Square, Edinburgh

Typeset in Plantin

by Koinonia, Bury, and

printed and bound in Great Britain

by The Cromwell Press, Trowbridge, Wilts

A CIP record for this book is available from the British Library

ISBN 0748622853 (hardback)

ISBN 0748623582 (paperback)

The right of Benjamin F. Soares to be identified as author of this work has been asserted in accordance with the Copyright, Designs and Patents Act 1988.

For other publications of the International African Institute, please visit their web site at www.iaionthe.net 